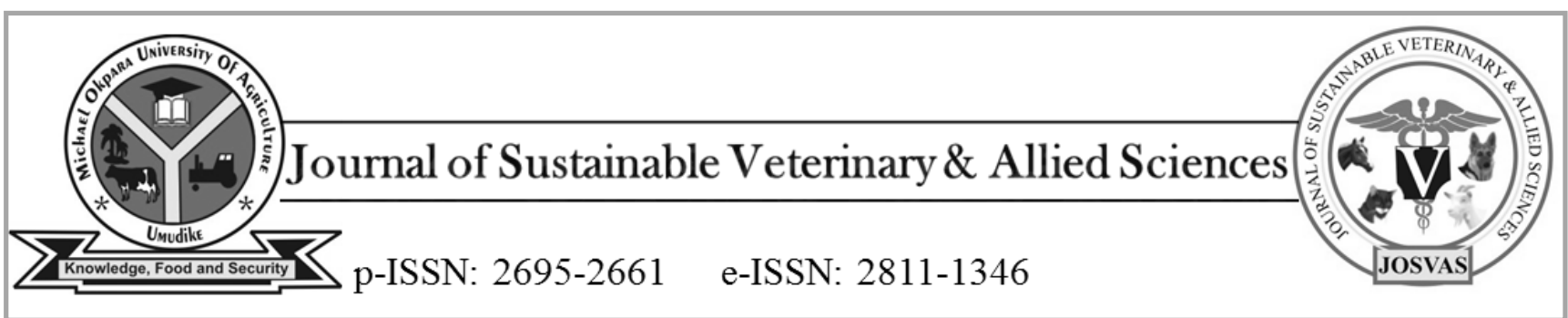

JoSVAS 2021, Vol 1, Issue 1: 56-61

C2021 College of Veterinary Medicine,

Michael Okpara University of Agriculture, Umudike, Nigeria

Original Research Article

\title{
Incidence of foetal wastage in goats in Umuahia, Abia state Nigeria
}

\author{
${ }^{1 *}$ Ani, N.V., ${ }^{1}$ Odirichukwu E. O., ${ }^{1}$ Anigbogu, L. O., ${ }^{2}$ Ifenkwe, D., ${ }^{3}$ Kalu, E. \& ${ }^{1}$ Raheem, K. A \\ ${ }^{I}$ Department of Theriogenology, ${ }^{2}$ Department of Veterinary Public Health and Preventive Medicine, ${ }^{3}$ Department of \\ Veterinary Physiology and Pharmacology, Michael Okpara University of Agriculture, Umudike, Nigeria
}

*Corresponding author: ani.nneka@ mouau.edu.ng +2348138453378

\begin{abstract}
This study investigated the indiscriminate slaughter of pregnant goats and the incidence of foetal wastage at Ahiaeke goat slaughter slab in Umuahia, Abia State for a period of 7 months (March - September 2018). A total of 518 goats were slaughtered during the period of study comprising $311(60.03 \%)$ males and $207(39.96 \%)$ females. The study revealed that majority $(76 \%)$ of the goats slaughtered within the study period were not inspected ante mortem while only $24 \%$ of the total goats were inspected prior to slaughter. In the course of the investigation, it was observed that out of the 207 does slaughtered, $130(62.80 \%)$ does were pregnant while 77 (37.19\%) were not. A total of 182 foetuses (109 males and 73 females) were recovered from the 130 pregnant does slaughtered. The highest number of slaughtered pregnant does was recorded during the traditional festive season, in August, resulting in high percentage (21.41\%) of foetal wastage during the study. Averagely, a monthly slaughter of $30(14.31 \%)$ gravid does was obtained. The slightly high rate of foetal wastage recorded in this study may be due to the very low coverage of ante-mortem inspection. Given the findings from this study, it can be inferred that poor ante-mortem inspection, ignorance on the part of farmers, butchers, and policy makers on proper management of pregnant animals in markets/slaughter slabs may have contributed to the foetal wastage and the slaughter of pregnant does.
\end{abstract}

Keywords: Foetal wastage, goats, slaughter slab, Umuahia.

\section{INTRODUCTION}

Indiscriminate slaughtering of pregnant animals in developing countries like Nigeria is a very pertinent issue that must be addressed if livestock productivity must be sustained. Foetal wastage has been identified as one of the major constraints to livestock production resulting in livestock shortage and protein malnutrition in developing countries. Factors contributing to foetal wastage include inadequate meat inspection practices resulting in slaughtering of pregnant animals (Abdulkadir et al., 2008; Muhammed et al., 2009; Cadmus \& Adesokan, 2010; Ardo et al., 2013), ignorance of the pregnancy status of animals by the livestock farmers and traders at the time of sale, increasing financial demands and infectious diseases predisposing the dam to abortion (Sanusi et al., 2006; Muhammed et al., 2009; Alhaji, 2011; Fayemi \& Muchenje, 2013).

The slaughter of pregnant animals in abattoirs and slaughter slabs calls for efficient ante-mortem inspections as well as provision of well-equipped Veterinary diagnostic tools that would facilitate improved herd health management in the country. Foetal wastage frustrates the efforts of livestock husbandry system in increasing animal production to meet the growing demand for animal protein by a growing human population. (Chaudhari \& Bokko, 2000; Addass et al., 2010; Ngbede et al., 2012).

There have been reports of foetal wastage in livestock in abattoirs globally with its attendant substantial economic losses (Maurer et al., 2016). Higher prevalence reports have been observed in African countries ranging from $1.3 \%$ to $45 \%$ (Nonga, 2015). Foetal wastage has predisposed some African countries to protein malnutrition and is a possible constraint to future livestock populations in the continent (Nwakpu \& Osakwe 2007; Ademola 2010; Cadmus \& Adesokan 2010). Poor financial condition of the farmers who are usually rural livestock farmers as well as the ignorance of the pregnant state of the animals have been 
advanced as reasons for culling and slaughtering of pregnant livestock (Sanusi et al. 2006; Muhammad et al. 2009).

In Nigeria, foetal wastage has been reported in cattle and small ruminants slaughtered at abattoirs and slaughter slabs (Nwakpu \& Osakwe, 2007; Addass et al., 2010; Cadmus \& Adesokan, 2010; Alhaji, 2011; Alhaji et al., 2015;; Ngbede et al., 2017; Ogunbodede \& Oladele, 2016; Raimi et al., 2017).

The high number of pregnant ewes and does slaughtered results in massive foetal wastages and pose great danger to the enhancement of small ruminant production (Ayodele et al., 2003).

Small ruminants (goats and sheep) are known to play significant roles in providing food and financial security in developing countries like Nigeria with particular allusion to rural dwellers (Alhaji \& Adetokun, 2013) and the vulnerable population (such as women). This implies that foetal wastage in small ruminants will predispose the rural and vulnerable population to financial losses and reduced income from livestock farming, decreased livestock productivity and works against the sustainable development goal (SDG) 2 focused on eradicating hunger.

Goats are major source of income to most people, especially the rural dwellers. The ability of goats to adapt to varying environmental conditions and the different nutritional regimes (Devendra, 1985) is highly recommended. Dunka et al. (2017) report that pregnant does are slaughtered on daily basis in slaughter slabs and abattoirs across the country and this facilitates the dwindling goat population in Nigeria. There is dearth of information on foetal wastage in Umuahia, Abia State. Therefore, this study was conducted to investigate the incidence of foetal wastage in goats in Umuahia municipality, a part of South Eastern Nigeria, where goats are bought, slaughtered and consumed with response to religious and cultural practices, taste preferences and demand rate. Findings from the present study will serve to enlighten the livestock producers, the live goat sellers, the butchers, the Veterinary personnel, the public and the government on the need for proper ante mortem inspection and ultimately the need for enhancement of livestock population, especially in goats through possible prevention of foetal wastage.

\section{MATERIALS AND METHODS}

\section{DESCRIPTION OF STUDY AREA}

The study was carried out at Ahiaeke slaughter slab, the only government approved slaughter slab for small ruminants in Umuahia Municipality, the capital city of Abia State. Abia state is geographically located in South East Nigeria and lies within approximate latitudes $4^{\circ} 40^{\prime}$ and $6^{\circ} 14^{\prime}$ north, and longitudes $7^{\circ} 10^{\prime}$ and $8^{\circ}$ east (Apeh et al. 2005). The state has a total land mass of $5,243.7 \mathrm{~km}^{2}$ with about 2.8 million people according to National Population Commission
(2006). Ahiaeke slaughter slab in the state capital has a thriving major goat market attached to it where live goats and goat meat are sold. The slaughter slab operates from Mondays to Saturdays with slaughtering commencing at 7 a.m. and ending at about 10.30 a.m. daily.

\section{STUDY PERIOD}

The study was carried out for seven months (March September, 2018). Daily visits were made to the abattoir to observe the slaughter of the goats and to collect the reproductive tracts from all the females slaughtered within the study period.

\section{SAMPLE COLLECTION AND IDENTIFICATION}

The reproductive tracts from the does slaughtered at slaughterhouse were collected immediately after slaughter to assess for foetal wastage. The collected samples were individually placed into a clean plastic bag, properly identified and taken to the Theriogenology Laboratory of Michael Okpara University of Agriculture, Umudike where the study was carried out.

\section{CALCULATION OF THE INCIDENCE RATES AMONG THE SEX OF GOATS SLAUGHTERED DURING THE STUDY:}

The incidence rate among the sex of the goats slaughtered was determined by expressing the total number of males or females slaughtered as a percentage of the total number of goats slaughtered.

\section{CALCULATION OF THE INCIDENCE OF ANTE MORTEM INSPECTION}

Data for the calculation of ante mortem inspection was collected following daily visits to the goat slaughter slab throughout the period of the study for an independent on-thespot investigation. The incidence of ante mortem inspection carried out by State Veterinary officers and animal health workers was calculated by expressing the number of times animals were inspected before slaughter as a percentage of the number of daily visits to the slaughter slab.

\section{ESTIMATION OF FOETAL WASTAGE AND GESTATIONAL LENGTH}

Reproductive waste (foetal wastage) was determined by expressing the foetuses recovered as percentage of the total female animals slaughtered (Bello et al., 2008).

The foetuses collected and identified were used for the estimation of gestational length/age as described by Hussein (2008). The crown - rump length of the foetus was obtained by measuring the length (in centimeters) from the forehead to the base of the tail to arrive at the possible foetal age (also estimated to be the gestational length in days).

Fetal age $=2.1(\mathrm{y}+17)$

Where, $\mathrm{y}=$ crown-rump length in $\mathrm{cm}$.

The foetal age (gestational length) is recorded in days as described by Noakes et al. (2001). 
The estimated ages of all the recovered foetuses were used in classifying the stage of pregnancy as follows: i) First trimester - for gestational lengths between one (1) and fifty (50) days, ii) Second trimester - for gestational lengths between fifty one (51) and one hundred (100) days and iii) third trimester - for gestational lengths between one hundred and one (101) and one hundred and fifty (150) days.

Following this, the estimated fetal ages were grouped into three different stages of pregnancy - first trimester, second trimester and third trimester. The presence of placentomes and gestational vesicles also served as indicators for pregnancy.

\section{DATA COLLECTION AND ANALYSIS}

Data obtained from the study were expressed as frequencies and percentages. Results were presented in tables and graph charts.

\section{RESULTS}

Within the study period, the total number of goats slaughtered was 518 of which $311(60.03 \%)$ were males and $207(39.96 \%)$ were females. The highest monthly slaughter was recorded in August (112 goats) while the lowest was in May (46) as shown in Table I.

The study revealed that majority $(76 \%)$ of the goats slaughtered and sold to consumers within the period of study were not inspected before slaughter while only $24 \%$ of the total goats slaughtered in the slaughter slab during this study were inspected ante-mortem as represented in Figure I

Two hundred and seven (207) does were slaughtered within the study period among which 130 does (62.80\%) were pregnant and 77 does $(37.19 \%)$ were not. The month of August recorded the highest number (28) of slaughtered pregnant goats as seen in Table II.

The incidence of foetal wastage is presented in Table III. Out of the total of 182 foetuses retrieved, 109 (59.89\%) of the foetuses were males while $73(40.11 \%)$ were females, giving a male : female ratio of $10.7: 7.4$. The highest recorded number of foetal wastage was 39 in the month of August. The monthly percentage of foetal wastage ranged from $6.04-21.42 \%$ with average monthly wastage calculated to be $14.31 \%$.

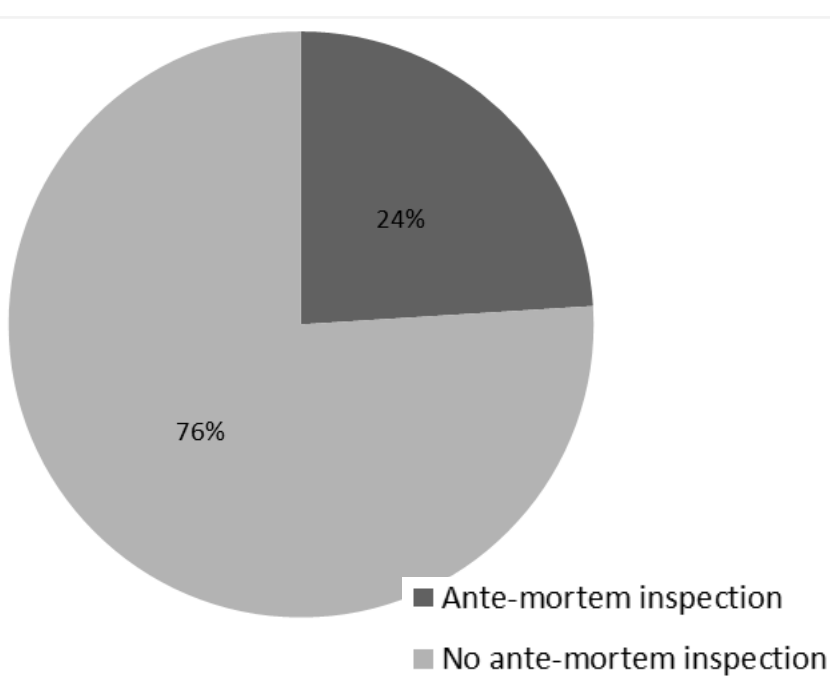

Fig. 1: Fig. 1: Incidence of ante-mortem inspection in Ahiaeke slaughter slab within the study period

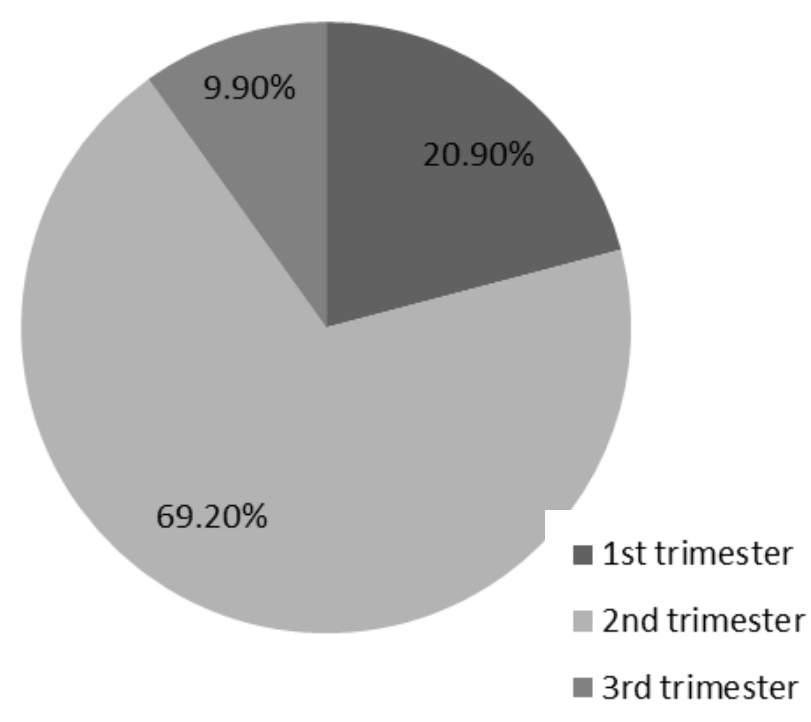

Figure II: Percentage of pregnant does slaughtered at Ahiaeke slaughter slab in Umuahia, Nigeria between March and September, 2018.

Table 1: Total number and sex of goats slaughtered in Ahiaeke slaughter slab, Umuahia, Nigeria between March and September, 2018.

\begin{tabular}{|c|c|c|c|c|c|c|c|c|}
\hline Parameters & $\begin{array}{r}\text { Months } \\
\text { March }\end{array}$ & April & May & June & July & August & September & Total (\%) \\
\hline $\begin{array}{l}\text { Total number of } \\
\text { goats slaughtered }\end{array}$ & 86 & 53 & 46 & 67 & 81 & 112 & 73 & 518 \\
\hline $\begin{array}{l}\text { Total number of } \\
\text { bucks slaughtered }\end{array}$ & 50 & 32 & 28 & 39 & 48 & 70 & 44 & $\begin{array}{c}311 \\
(60.03 \%)\end{array}$ \\
\hline $\begin{array}{l}\text { Total number of } \\
\text { does slaughtered }\end{array}$ & 36 & 21 & 18 & 28 & 33 & 42 & 29 & $\begin{array}{c}207 \\
(39.96 \%)\end{array}$ \\
\hline
\end{tabular}


Table II: Number of pregnant does slaughtered monthly at Ahiaeke slaughter lab, Umuahia Nigeria between March and September, 2018.

\begin{tabular}{rcccccccc}
\hline Parameters & $\begin{array}{c}\text { Months } \\
\text { March }\end{array}$ & April & May & June & July & August & September & Total (\%) \\
\hline $\begin{array}{r}\text { Total number of doe } \\
\text { slaughtered }\end{array}$ & 36 & 21 & 18 & 28 & 33 & 42 & 29 & 207 \\
$\begin{array}{r}\text { Total number of non- } \\
\text { pregnant does slaughtered } \\
\text { Total number of pregnant } \\
\text { does slaughtered }\end{array}$ & 14 & 8 & 6 & 11 & 13 & 14 & 11 & $77(37.19 \%)$ \\
\hline
\end{tabular}

\section{DISCUSSSION}

The slaughter of goats for meat is on the increase, and this could lead to continuous depletion of the goat population if pregnant goats are slaughtered (Ataja \& Uko, 1994). Indeed the slaughter of pregnant animals is a well-recognized source of wastage especially by abattoir personnel, Animal Scientists and Veterinarians (Ojo et al., 1978; Ataja et al., 1997). Ideally, sound economic livestock management, demands that animals sold for slaughter should be mainly males and reproductively inactive females (Opara et al., 2006; Riehn et al., 2010). This is contrary to the regular practice of slaughtering productive, clinically healthy livestock at different gestational stages for meat.

During the seven - month period of this study, the total number of goats slaughtered was 518 out of which 207 were females and 311 were males. This implies that majority (60.03\%) preferred to slaughter bucks while $39.96 \%$ preferred does. The highest monthly slaughter was recorded in August (112 goats) while the lowest recorded goats slaughter figure was in May (46).The highest monthly slaughter recorded in August (112) could be alluded to the increased demand of goat meat associated with the season of new yam festival, a traditional ceremony in Umuahia. This finding agrees with Wosu (1988) and Akpabi \& Babalola (2014) who reported that season or period of the year as a major factor contributing to the high rate of slaughter of pregnant animal. Religious and traditional ceremonial activities are not the same for all the months of the year. Rather, they vary and the period coinciding with these activities definitely record more slaughter of animals such as goats for entertainment of guests and families.

The result of this study revealed very poor ante-mortem inspection $(24 \%)$ on the goats prior to slaughter at the slaughter slab throughout the period of this study which may have contributed to the high number of pregnant does slaughtered. This agrees with the findings by other studies (Wosu \& Dibua, 1992; Bello et al., 2008; Terzungwe \& Danjuma, 2010) that thorough ante-mortem examination is lacking at the various goat markets/slaughter slabs, which may have contributed to the high number of foetal wastage reported in such places. The low rate of ante mortem inspection in slaughter slabs could possibly be due to few numbers of Veterinary Doctors and animal health personnel employed by the State government. Another cause of foetal wastage is ignorance of the livestock farmers and traders as well as abattoir workers on the reproductive status of the does prior to slaughter. In the course of this study, majority of the fetuses recovered from the slaughtered pregnant does were within the first and second trimesters. At the first and second trimester, it is usually difficult to detect pregnancy by simple ballottement especially for the untrained farmers and abattoir workers where the Veterinary personnel is not available.

It was observed that within the period of this study that, 130 out of the 207 does slaughtered were pregnant at various gestation lengths and a total of 182 foetuses were recovered, with $40.11 \%$ of them being females. This result portends great danger to the reproductive efficiency of the goat population in Umuahia, as more females are required in reproductive processes. This agrees with the assertion of Ayodele et al., (2003) who reported that the practice of slaughtering female animals is a deterrent to animal production.

The average monthly percentage of foetal wastage (14.31\%) obtained from this study in Umuahia was higher than the 3.9 $\%$ reported in Benue State (Oyekunle et al., 1992)). $4.44 \%$ in Niger State (Cadmus \& Adesokan, 2010), $8.2 \%$ obtained in Ogun State (Fayemi et al., 2008), and $9.15 \%$ reported in Ebonyi State by Nwakpu et al. (2007).

The findings in this study also showed that one foetus was wasted for every two to three goats slaughtered. This ratio is higher than the ratio of 1:14 and 1:4 reported by Fayemi et al., (2008) at four abattoirs in Ogun State and Nwakpu \& Osakwe (2007) in Ebonyi State of Nigeria, respectively. Also Ndi et al. (1993) reported a ratio of 1:4 from a study conducted in Cameroon goat abattoir. This showed that the foetal wastage in Ahiaeke goat slaughter slab is quite alarming and effort should be geared towards instituting daily ante mortem examination of the goats prior to slaughter with emphasis laid on pregnancy diagnosis. This will help 
abate the rising menace of dwindling goat population especially with rapid increase in population of the country, and demand for animal protein especially if we are to meet the Food and Agricultural Organization (FAO) required recommendation of $35 \mathrm{~g} / \mathrm{head} /$ day of animal protein for good health in human population which is a far cry from the average consumption of $4.5 \mathrm{~g} / \mathrm{head} /$ day reported in Nigeria (Atsu, 2002).

Care should be taken to curb the destruction of embryos and foetuses at slaughter slabs to prevent the eventualities of future importation of goat meat into the country to make up for the wastage at various abattoirs (Bokko, 2011).

The results obtained from this study ascertain that foetal wastage occurs in Ahiaeke goat slaughter slab, Umuahia. Foetal wastage is a common finding and it is recorded almost daily across abattoirs/slaughter slabs in Nigeria. This is very similar to the findings reported by Bello et al. (2008), Abdulkadir et al. (2008), Oduguwa et al. (2013), Ardo et al. (2013), Odeh et al. (2015) and Mshelia et al. (2015).

\section{CONCLUSION}

Findings from this study point to the fact that some factors like inconsistencies in ante mortem inspection on the goat before slaughter, ignorance on the part of farmers, butchers, and policy makers on proper management of pregnant animals in the market/slaughter slabs may have contributed to the foetal wastage and the slaughter of pregnant does recorded within the period of study. It is necessary for the State to employ more Veterinarians and distribute them to all the registered abattoirs/slaughter slabs to ensure proper and strict ante mortem inspections. Strict policies prohibiting the slaughter of pregnant animals should be created and implemented. Public enlightenment on the adverse effects of foetal wastage on livestock productivity is also very pertinent if foetal wastage will be drastically reduced.

\section{REFERENCES}

Abdulkadir, U., Jiya, E.Z. \& Kosu, S.A. (2008). Survey of Foetal Wastages: A Case Study of Makurdi Abattoir in Benue State from 1997 to 2002. Pakistan Journal of Nutrition, 7(3): 450-452.

Addass, P.A., Midau, A., Milka, M. \& Tizhe, M.A. (2010). Assessment of Abattoir foetalwastage of cattle, sheep and goat in Mubi main Abattoir Adamawa State, Nigeria.World Journal of Agricultural Sciences, 6(2):132-137.

Ademola AI (2010) Incidence of fetal wastage in cattle slaughtered at the Oko-Oba Abattoir and Lairage, Agege, Lagos, Nigeria. Journal of Veterinary Research, 3(3):54-57

Akpabio, U. \& Babalola, S.A. (2014). Fetal Wastage in Goat s Slaughtered at Trans-Amadi Abattoir Portharcourt, Nigeria. Global Veterinaria, 13 (2): 255 257.

Alhaji, N.B. (2011). Prevalence and economic implications of calf foetal wastage in an abattoir in North central
Nigeria. Tropical Animal Health and Production, 43: $587-590$.

Alhaji, N. B. \& Odetokun, I. A. (2013). Food security and economic implications of small

ruminant fetal wastages in Nigeria: A case of an abattoir', Livestock Research for Rural Development, 25: 5.

Alhaji, N. B., Odetokun, I. A., Shittu, . A, Onyango, J., Chafe, U. M. \& Abubakar, M. S. (2015).

Time-series analysis of ruminant foetal wastage at a slaughterhouse in north central Nigeria between 2001 and 2012. Onderstepoort Journal of Veterinary Research, 82(1): 13.

Apeh, M., Chigbu, N. \& Chigbu, A. (2005). Vectorisation and database creation of Abia State Polytechnic Aba, Nigeria with geographic information system (GIS). Proceedings of the FIG working week conference, 17 - 21 May, 2005 held in Sofia, Bulgaria.https://www.fig.net/resources/proceedings/ fig_proceedings/fig2015/ppt/TS06D/TS06D_apeh_ chigbu_et_al_7869_ppt.pdf.

Ardo, M. B., Lawal, H. \& Aliyara, Y. H. (2013). Economicimplication of bovine foetal wastage in Yola modern abattoir, Adamawa State, Nigeria. International Journal for Agro Veterinary and Medical Sciences, 7(2):57-64.

Ataja, A. M. \& Uko, O. J. (1994). Slaughter of the single humped camel for meat at the Sokoto abattoir, Nigerian Journal of Animal Production, 21: 181 183.

Ataja, A. M. Uko, O. J. \& Tambuwal, F. M. (1997). Pregnancy in slaughtered cows at Sokoto abattoir, Nigeria. Nigerian Journal of Basic and Applied Sciences, 7: $1-4$.

Atsu, D.W. (2002). Contributory role of animal production in national development. Book of Proceedings of the $7^{\text {th }}$ Annual Conference of Animal Science Association of Nigeria (ASAN), September $16^{\text {th }}-19^{\text {th }}$ ::171-173.

Ayodele, A.O., Fadiyimu, A.A, Folorunsho, O.R. \& Olowu, O.P.A (2003). Foetal wastages

through the slaughtering of pregnant cows in Akure abattoir. Proceedings of 28th conference of Nigeria Society of Animal Production, 2: 45-51.

Bello, M.B., Garba, H.S. \& Sofada, M.L. (2008). Foetal wastage in camels slaughtered at Sokoto Municipal abattoir. Sokoto Journal of Veterinary Sciences. 7(1), 46-49.

Bokko, P. B. (2011). Pregnancy wastage in sheepand goats in the Sahel region of Nigeria. Nigerian Veterinary Journal. 32(2):120-126.

Cadmus, S.I. \& Adesokan, H.K., (2010). Bovine foetal wastage in south western Nigeria: a survey of some abattoirs. Tropical Animal Health and Production, 42(4), 617-621.

Chaudhari, S.U.R. \& Bokko, P. B. (2000). Reproductive status, pregnancy wastage and incidence of gross genital abnormalities in cows slaughtered at Maiduguri abattoir, Nigeria. Pakistan Veterinary Journal, 20(4):203-205. 
Devendra, C. (1980). The potential of sheep and goats in the less developed countries. Journal of Animal Science, 51: 461-473.

Dunka H. I., Buba, D.M., Gurumyen, Y.G., Oragwa, A.O., Oziegbe, S.D.and Patrobas M.N. (2017). Economic losses associated with the slaughter of pregnant animals in Jos abattoir. International Journal of Advanced Research,5(7): 1047-1052.

Fayemi, P.O. \& Muchenje, V. (2013). Maternal slaughter at abattoirs: history, causes,cases and the meat industry. Springer Plus, 2 (125): 1-8.

Fayemi, A.O., Taiwo, B.B.A., Okubanjo, A.O. \& Adekunmisi, A.A.(2008). Frequency of slaughtering gravid cows in some selected parts of Ogun State. In: Proceedings of the 33rd Annual Conference of the Nigeria Society of Animal Production. Pp: 234-237.

Hussein, A.A.(2008). Determination of first pregnancy and foetal measurements in Egyptian Baladi goats (Capra hircus).Veterinaria Italiana, 44(2):429-37.

Maurer, P., Lücker, E. \& Riehn, K. (2016). Slaughter of pregnant cattle in German abattoirs current situation and prevalence: a cross-sectional study. BMC Veterinary Research, 12,91. https://doi.org/10.1186/s12917-016-0719-3

Mshelia, G. D., Maina, V. A. \& Aminu, M. D. (2015). Foetometrics and Economic Impact Analysis of Reproductive Wastages in Ruminant Species Slaughtered in North-Eastern Nigeria. Journal of Animal Production Advances, 5(4): 645-653.

Muhammad, B.F., Haruna, I.Y., Abdulsamad, A.M. \& Bichi, J.M. (2009). Foetal wastage in Northern Nigerian: The case of Gombe abattoir, Gombe State. Proceedings of the13th Annual Conference of Animal Science (ACAS '08). ABU, Zaria 13:124127.

National Population Commission, NPC. (2006). Nigerian population census report 2006.

Ndi, C., Tambi, N.E. \& Agharih, N.W. (1993). Reducing calf wastage from the slaughtering of pregnant cows in Cameroon. World Animal Review, 77: 4- 10.

Ngbede, E. O., Hena, S. A., Oguntoye, O. O., Tarhyei, R. \& Bulus, C. (2012) Bovine foetal wastage and economic implication; a six year (2003 - 2008) retrospective study in an abattoir in northwestern, Nigeria. Scientific Journal of Veterinary Advances. 1 (2): 42-46.

Noakes, D. E., Parkinson, T. J. and England, G. C.W., (2001). Pregnancy and its diagnosis. In:

Veterinary Reproduction and Obstetrics, 8th edition, Saunders Elsevier, UK. Pp. 106-110.

Nonga, H. E. (2015). A review on cattle foetal wastage during slaughter and its impacts to the future cattle herds in Tanzania. Livestock Research for Rural Development. 27, No. 251.

http://www.lrrd.org/lrrd27/12/nong27251.html.

Nwakpu, P.E. \& Osakwe, I.I.(2007). Trends in volume and magnitude of foetal waste of slaughter animals(2000-2005) in Ebonyi State of Nigeria. Research Journal of Animal Science, 1: 30-35.
Ogunbodede, M. A. \& Oladele, G. M., (2016). Wastage of bovine conceptus through indiscriminate slaughter of pregnant cows at Bodija central abattoir, Ibadan. Journal of Agricultural and Crop Research 4: 6065.

Odeh, S., Dawuda, P.M., Oyedipe, E.O. \& Obande, G.E. (2015). Incidence of foetal wastage in slaughtered cattle at Wurukum abattoir,Makurdi, Benue State. Vom Journal of Veterinary Sciences, 10(1):41-50.

Oduguwa, B.O., Raimi, C.O., Talabi, A.O. \& Sogunle, O.M. (2013). Fetal Losses from Slaughtering Pregnant Cows at Lafenwa Abattoir in Abeokuta, South Western Nigeria. Global Journal of Biology, Agriculture and Health Sciences, 2 (2):38-41.

Ojo, S.A., Dennis, S.M. \& Leipold, H.W. (1978). Pregnancy in slaughtered cows in Zaria:Relationship to age, season, stage of gestation and carcass weight, Nigerian Veterinary Journal, 6: 66-75.

Opara, M.N., Okoli, C.I., Herbert, U. \& Adeyemo,O. (2006). Ovarian morphology and estradiol-17 concentrations in serum and follicular fluid of slaughtered zebu cattle in Ibadan. Nigeria Veterinary Archives, 76(5):403-411.

Oyekunle, M.A., Olubanjo, O.O. \& Fasina, O.E. (1992). Foetal Wastage in abattoirs and its implication. Situation report from Ogun State, Nigeria. Nigerian Journal of Animal Production. 19:57-63.

Raimi, C.O., Oduguwa, B.O. \& Bamgboye, F.O., (2017). Slaughtered cattle and reasons for slaughtering of cows in Ember months at Lafenwa abattoir in Abeokuta, Nigeria European Journal of Agriculture and Forestry Research. 5, 1-8

Riehn, K., Domel, G., Einspanier, A., Gottschalk, J., Hildebrandt, G., Luy, J. \& Lucker, E. (2010). Slaughter of pregnant cattle- ethical and legal aspects, 90th edn. Deutscher Fachverlag, Frankfurt am Main, Allemagne (Revue). Pp 100-106.

Sanusi, M., Abubakar, M. \& Luka, B. (2006). Incidence of foetal wastage in ruminant animalsslaughtered at Bauchi and Jos abattoirs. Proceedings of the 31st annual conferenceof the Nigerian Society for Animal Production (March 12-15) Bayer University, Kano, Nigeria. 31:102-106.

Terzungwe, A. \& Danjuma, Z. (2010). Species contribution as source of meat and their wastage in Taraba State, Nigeria. Archives of Applied Science Research. http://www.scholarsresearchlibrary.com

Wosu, L.O. (1988). Calf wastage throughslaughtering of pregnant cows in Enuguabattoir, Nigeria. Revue Elevage Medecine Veterinaire Pays Tropicaux, 41(1):97- 98.

Wosu, L.O. \& Dibua, E.C. (1992): Lamb and kid wastage through slaughtering of pregnant ewes and goats at Enugu and Nsukka abattoirs in Anambra State, Nigeria. In: Rey, B., Lebbie, S.H.B. and L. Reynolds (Eds). Small ruminant research and development in Africa. Proceedings of the first biennial conference of the African small ruminant research network. ILRAD, Nairobi, Kenya. 